\title{
EFFECT OF REMATING INTERVAL AND WEANING AGE ON SOME PRODUCTIVE TRATTS IN RABBIT
}

\author{
Fouda, M. M. 1; E1-Bayomtb, Kh. M. ${ }^{2}$ and Ghanema, H. M. \\ 1Department of Antrnal Husbandry: Faculty of Velerinary. Medicine, Mansousa Unlversity.

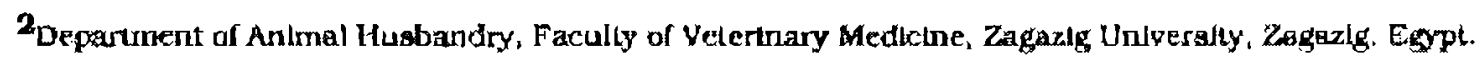

\begin{abstract}
The productivity of rabbits depends mainly on the number of young unaned per cage, which can be increased by maximling the number of parturtions and minimizing the intervals between then. providurg the stze of liters as maintained. The atm of this study was therefore to investigate the effect of three different remating interwals as well as two different weaning ages on the productive traits (body weight, ctally feed consumptorn, post weaning growth, mortalty and viabillty. The experimental flock composed of six groups, each group consists of elght does of NZW Rabbit remated $(1,5,10)$ days postpartum and useaned their kits at $\left(25\right.$ and $35 d$ of age). Does mated $5^{\text {ih }}$ day post-partum and thelr litters weaned at 35 days of age showed significant ( $p 0.05$ ) itgher body weights at different ages, htgher RGR\% and average dally gatn Does mated $1^{\text {st }}$ day past prortum and their ittiers weaned at 25 days of age showed inferior body weight through the whole experimentiol pertad.
\end{abstract}

\section{INTRODUCTION}

Rabbits are ralscd for a vanety of reasons and are found vitually in every country. Keeping of rabbits for meat production has a great important for the developing countres. Rabbits have traditionally treen ralsed by small farmers in these developing countries to cover the severe shortage in meat production due to the increase in human population. One of the most interesting princlples in the 1unanagement of farm rabbits is selection of the sultable time or mating after parturtion espechally under the intenslyc productlon system. Remating interval can be as short as one day after parturition. Farmers usually plan a remating interval of 1 to 2 days (inteusive production). 7 to 14 days (sempintensive) or 14 days on wards (extensive), and in general does with small utters are usually presented to the male immedlatcly post partum. but most cxpertments have shown greater acceptance of the male but lower conception rate when does are inated imumedlately post partum. The present study was therefore carried out to invesugate the effect of three different remating intervals as well as two different weaning ages on the productive traits including: preweaning growth (body welght, dally feed eonsumptlon). post weaning growth, mortallty and viabllty.

\section{MATERLALS AND METHODS}

This study was condueted at the Rabblts Unit belonging to the Department of Anlmal Husbandry and Wealth Development, Faculty 
of Veterinary Medlelne Mansouta University during the pertod extended from September 2007 untll June 2008.

\section{Flock hlotory and mandgement:}

The flock composed of 24 docs and 5 bucks of mature New Zealand White Rabbits (NZW) welghing $3.0-3.5 \mathrm{~kg}$ and $5-6$ months of age. All the experimental animals were reared under the game entronmental condtelons. Good ventulatlon and fresh air was also pro vided to reduce ammonla concentration in the house. The andmals were handled according to the principles for care of anlmais in expertmentation. Lasbbits of all ages were fed commercial pelieted ration obtaned from foUDA Company.

\section{Doos and mating management:}

Each doe was Introduced to the buck's cage. Mating of the doe was executed two times to burks of proven fertlity. Doe, buek rumber and date of mating were recorded, then each doe palpated for pregnancy 14 days alter service. For posituvely palpated does, the expected date of kundling is recanded. while, negattvely palpated dose were remated. At $26^{\text {th }}$ or $27^{\text {th }}$ day of gestation, clean disinfected with some rice straw kindling box is providcd for each doe's cage.

\section{Experimental deolgn:}

The present work was planned to evaluate the effect of rematung interval and weanirh age on the productive tralts in New Zealand White Rabbits (NZW). Before the beginning of this expermental study, all does were mated almost at the same date to test the reproductlon performance of the foundation stock in their frst partly. Next to the first party, does were divided according to post partum triterval of mating into three groups each of 8 does. Does in the first group were remated through the day following kdndling. does in the second group were remated on $5^{\text {th }}$ day post partum and does in the third group were remated on $10^{\text {th }}$ day past partum. Moreover, each mating group was weaned at two differcalt ages (25 and 35 days).

\section{RESULTS AND DISCUSSION}

Table (1) showed least squares means. standard errors and test of signtficance of differences among means of preweaning relatlye growth rate ratio (25 days) and preweaning relative growth rate ratio ( 35 days) due to the effect of remating interval, weaning age and their Interaction. Remating interval, weaning age and thelr Interaction had non signiffcant eflects un preweaning relattve growth rate durtig the first 25 and 35 days of age lweanIng age). Durng the first 25 and 35 days of age. the highest preweaning relative growth rates (64.64\% and 72.834\%, respectively) were obtalned Irom does mated 5th day postpartum, then the relative growth rates of litters (61.34\% and $71.54 \%$, respectively) from does mated $10^{\text {th }}$ day post-partum. whlle the lowest relative growth rates of litters (61.24 and $70.00 \%$, respectuvely) obtalned from does mated $1^{\text {st }}$ day post-partum. Moreover, the higheat preweaning relative growth rate of litters (62.5890́) was obtalned from does weaned at 25 days weaning age. whlle the lowest preweanlng relative growth rate of litters (62.239) obtained Irom does weaned 35 days weaning age. As Interaetion effeet. the highest relative growth rales $(65.54$ and 72.8790$)$ were obtalned in does mated $5^{\text {th }}$ day post-partum with 25 and 35 days weaning age, respective- 
ly, whlle the lowest relatlve growti rates of litters (60.96 and $71.549 \%$ ) obtalned from does mated $1^{\text {st }}$ day post-partum and litters weaned at 25 and 35 days weaning age, respectively. These results were inagreements with chen et al. (1978), Rao et al. (1978), Romney and Johnson (1978), Benras and Frlend (1981), De Blav et al. (1981), Diwyanto et al. (1985), Fekete and Gippen (1985). Toon et al. [1995), Aroz (1096) and Das et al. (2007) they reported that weaning age affected non signiflcantly on relative growth rale and delayed weaning age are preferable than early weaning

Table (2) showed least squares means, standard errors and test of significance of diflerenees among means of relative growth rate ratto during the pertod from 6-8 and 8.10 weeks of age. Results lndicated that remating interval, weaning age had signillcant effeets (p $\leq 0,05)$ on relative growth rate durnig the pert. ad from 6-8 and 8-10 weeks of age, while the interaction had a stgnificant effect ( $\mathrm{ps} 0.05$ ) from 6-8 weeks of age and norr signtflcant effect (p > 0.05) from 8-10 weeks of age. During the perlod from 6-8 and 8-10 weeks of age. the highest relative growth rates $(44.28$ and 33.869\%, respectively) were obtatned from does mated 5 th day post-partum, then the relative growth rates of litters $(42.77$ and $32.89 \%$, respectively] obtained from does mated lst day post-partum, whlle the lowest relative growth rates of litters $(33.82$ and $30.82 \%$, respecturely) obtalned from does mated loth day post partum. Moreover, the highest relative growth

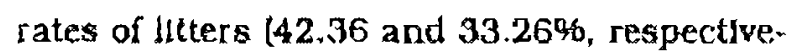
ly) were obtained from does weaned at 35 days weaning age, whlle the lowest relative growth rates of litters $(38.23$ and $31.79 \%$, respcctively) obtained from does wearued 25 days weaning age. For the Interaction effect, the highest relative growth rates ratio were obtained from does maled $5^{\text {th }}$ day postpartum with 35 days weaning age which average 48.94 and $35.61 \%$, respectlvely, while the lowest relative growth rates of hitters 133.58 and $30.02 \%$. respeetlvely] obtalned from does mated $10^{\text {th }}$ day post-partum with 25 days weaning age. This may be agreed with the related ngures of body weight at 6-8 weeks of age. These results were inagreements whth Toson et al (1995) as they reported that average daily gain (4-6 weeks) of rabbits produeed by dops remated later after partuntion were sig. rificantly lower than those of rabbils produced by does remated earller aster parturtion.

Table (3) showerl least squares means, standard errors and test of slgniffcance of dufferences among means of relatue growth rate ratio due to the effect of remating interval, weaning age and their Interaction during 10 12 and $12-14$ and 14-16 weeks of age. Remating interval and interaetlon had non stgnincant effeet on the relative growth rate ratio ( $p>0,05)$, while weaning ages had a significant effect (ps0.05) from 10-12 and 12-14 weeks of age. From $10-12$ and $12-14$ weeks of age, the highest ratto were obtained from does mated $5^{\text {th }}$ day post-partum which averaged 24.62 and $24.62 \%$. respectlvely, then the relative growth rate of litters $(21.73$ and $17.85 \%$, respectuvely] obtained from does mated $1^{\text {st }}$ day post-partum, whlle the lowest relatuve growth rate of litters 122.61 and $17.78 \%$, respectively) from does mated loth day post-partum. For weaning age effeet, the highest relative growth rates of ltters $(26.53$ and $19.36 \%$, respectively) werc obtained from does weaned at 35 days weaning age whlle the lowest relative 
growth rates of Hiters 119.44 and $17,04 \%$, respectrvely) obtained from does weaned 25 days weaning age. For the Interaetion effeet, the bughest relative growth rates were obtaned from does mated $5^{\text {th }}$ day post-partum with 35 days weaning age which average 29.38 and $20.50 \%$, respectively, while the lowest relative growth rates of litters (19.04 and $15.85 \%$, respeettvely) oblained from does inated 10 th day prost-partum with 25 days weaning age. At 14-16 weeks of age weaning age only had a signifleant effect (ps0.05) on growth rate ratlo, while remating interval and intcraction had non slgnifleant effeets (p>0.05). Results revealed that the highest relative growth rate ratlo (16.09\%) was obtalned Irom does mated $5^{\text {th }}$ day post-partum. then the relatuve growth rate of litters $(15.21 \%)$ from does mated $10^{\text {th }}$ day postpartum. while the lowest relative growth rate of litters (14.94\%) obtalned from does mated $1^{\text {st }}$ day post-partum. For weaning age effect. the highest relative growth rate of lithers (16.13\%) was obtulned from does weaned at 35 days weanlng age, whlle the lowest relatwe growth rate of llttery (14.69\%) obtained from does weaned 25 days weaning age. As the interaction eflect, the highest relatve growth rate rato (17.49\%) was obtalned from does mated $5^{\text {th }}$ day post partum with 35 days weaning age. whlle the lowest ratio were obtatned from does mated 10 th day with 35 days weaning agr (14.29\%). These results were Inagreements with Purtridge et al. (1984) and Mendez et al. (1086).

Table (4) showed least squares mearss. standard errors and test of significance of difference for means of dadly galn at the first 25 and 35 days of age due to the effect of remat-
Ing interval, weaning age and thelr interaction. At 25 day and 35 days of age, both weaning age and interaction had non signtfeant elfects ( $p>0.05$ ), while nematung Interval had a signiflcant effeet ( $p \leq 0.05$ ) on dally gain at the frst 25 days of age and a non signtheant effect $(p>0.05)$ at 35 days or age. For 25 and 35 days of age, the hughest average dally gatn (47.34 and $55.55 \mathrm{~g}$, respectively) were obtalned from does mated $5^{\text {th }}$ day postpartum. then the average dally galn of litters (42.18 and 54.33 g. respectively) from does mated $10^{\text {th }}$ day post-partum, while the lowest dally gain of Htters $(37.05$ and $47.56 \mathrm{~g}$ re spectuvely) obtalned from does mated ist day post-partum. For weaning age effect. the highest dally galn of litters $(43.34 \mathrm{~g}$ ) was obtained from does weaned at 25 days weaning age.As Interaetion efrect, the highest average dally gain $(48.41 \mathrm{~g})$ was obtained from does mated $5^{\text {th }}$ day post-partum with 25 days weaning age, whlle the lowest ratio obtatned from does mated $5^{\text {th }}$ day with 35 days weaning age (36.94 g). For the group weaned at 35 days weanlng age, the highest average dally gatn $(55.50 \mathrm{~g})$ was obtained from does mated $5^{\text {th }}$ day post partum with 35 days weaning age. whlle the lowest ratlo $(47.50 \mathrm{~g})$ obtained from does mated $1^{\text {th }}$ day with 35 days weaning age. These results were inagreements with Asoz [1906).

Table (5) showed least squares means. standard errors and test of signiflcance of dIfrerenee among means of the average dadly galn during 6-8 and 8-10 weeks of age due to the effect of remating interval, weaning age and their interaetion. Remating interval, weaning age and interaction had signineant effeets on average dally gain (ps0.05) during 
6-8 and 8-10 weeks of age. The highest dally gain was obtained from does mated 5th tay post-partum (24.05g and 25.76 g. respecthely) for 6-8 and 8-10 weeks of age. then the average dally galn of litters (23.15 and 24.69 g. respertivelyl from does mated $1^{\text {st }}$ day post. partum, whille the lowest relative growth rate of litters (18.38 and $23.65 \mathrm{~g}$. respecuvcly) from does mated 10 th day post-partum. Moreover, the highest dally galn of litters (25.31 and $27.25 \mathrm{~g}$ respectively] were obtained from does weaned at 35 days weaning age. whlle the lowest dally gain of litters (18.4) and $22.15 \mathrm{~g}$, respeetuelyl oblained from does weaned at 25 days weaning age during 6-8 and 8.10 weeks of age. For interaction effect. does mated 5thday post-partum with 35 days weanlng age had the highest dally gain (29.25 and $28.6 \mathrm{~d}$ \&. respectlvely\}, while the lowest dally galn (15.03 and $21.36 \mathrm{~g}$, respectively) was obtatned from does mated 10th day post. partum with 25 days weaning age. These results were inconsistent with Gallols et al. (2003-2004) and Azoz (1996) they showed that the body welghts of rabbits weaned at 21 days were smaller (-996) than these of rabbits weaned at 35 days belween the ages of 28 and 49 days, Also. dally weight galns were signiflcantly lower in early weaned rabbits untal day $42\{-170, P>0.05\}$, but not therealter.

Table (6) showed least squares means. standard errors and test of significance of difference among means of the average daily gain durtng 10-12, 12-14 and 14-16 weeks of age weeks of age due to the effect of remating interval. weanlng age and thetr interacton. Rematurng interval. weaning age. and interactoon had non signflicant effects on the average daily gain $(p>0.05)$ during $10-12$ and $12-14$ weeks of age. The highest daily gains were obtalued from does mated 5 th day post-parium \{24.58 and $22.25 \mathrm{~g}$. respectuvely\} during $10-12$ and $12-14$ weeks of age, then the average dally galn of luters 23.75 and 22.14 g. respectuvely) Irom does mated 10 th day postpartum. whlle the lowest relauve growth rate of litters (20.84 and $22.11 \mathrm{~g}$ respuctively) obtalned from does mated 1 stday post-partum. Moreover, the highest dally gains of lltters (24.05 and $22.68 \mathrm{~g}$, respectuvely) were obtadned from does weaned at 35 days weaning age, whlle the lowest dally galns or litters \{22.07 and 21.66 g. respectluely) obtalned from does weaned 25days weantrig age durIng 10-12 and 12-14 weeks of age For interaction eflect, does mated $5^{\text {th }}$ day post-partum with 35 days weanirng age had the highest dally galns $(26,32$ and $24.27 \mathrm{~g}$. respectuvely). whlle the lowest dally gains (20.50 and 20.22 g. respectlyely) were obtalned from does mated first day wtth 35 days weandng age during 10-12 and $12-14$ weeks of age. These results were In agreements with Das et al. (2007) as they found that there was non-signiflcant of fect $(p>0.05)$ of weaning age, on post weanlng average dally galn. At 14-16 weeks of age weaning age only had a significant effect of the average dally gain ( $p \leq 0.05$ ) whlle remalung Interval and interactlon showed non signilncant effects on the average dally $(p>0.05)$. There were no dfference among the three remated groups whych averaged $22.10,22.55$ and $22.63 \mathrm{~g}$ for the three remated groups $\mathrm{i}^{\text {st }}$. $5^{\text {th }}$, and $10^{\text {th }}$ day post-partum, respectlvely. Moreover, the highest dally gain of litters $(23.55 \mathrm{~g}$ was obtalned from does weaned at 35 days wcaning age. whlle the lowest dally gain of litters $(21.31 \mathrm{~g})$ ubtalned from does weaned 25 days weaning age. As interaction 
eflect. the highest dally gan (25.10 g) was obtalned from does mated $5^{\text {th }}$ day post-partum with 95 days weaning ages, whlle the lowest dally gain of litters $(20.01 \mathrm{~g})$ obtatned from does mated $1^{\text {st }}$ day post-partum with 35 days weaning ages during 14-16 weeks of age.

Table (7) showed least squares means, standard errors and test of stgnificance of difference of carcass cuts (forepart \%, Intennedate 96 and hind part \%) due to the eflect of remating interval, weaning age and their interacuon. Remating interval, weaning age and thelr interaction had ( $p \leq 0.05)$ sigriticant effects on fore part and intermediate part percent and non sigrulncant effect ( $>0.05$ ) on the hind part percent. The highest fore part, intermediate part and hind part percents 22.30 . $20.20,25.10 \%$ and $22.30,20.19,25.10 \%$ were obtalned from does mated 5 th and $10^{\text {th }}$ day post-partum, respectlvely, whlle the lowest percents $(19.10,18.70$ and 23.70\%) for the three cuts were obtained from does mated $1^{\text {st }}$ day post-partum. respectively. For the weaning age cffect, the hlghest percent for the three previous culs (22.6. 20.40 and 24.40\%) were obtalned from group of litters weaned at 35 days of age, respectuvely, whlle the lowest pereents (19.9. 17.40 and $23.50 \%$ ) for the three cuts obtained from group of litters weaned al 25 days of age, respectively. As tinteraction effect, the highest percents for the three cuts $(26.20 .22 .61,26.40$ and 26.19 . $22.60,26.3996$ ) were obtained from does mated $10^{\text {th }}$ and $5^{\text {th }}$ day post-partum with 35 days weantrig ages. respectwely, whlle the Lowest percents for the three cuts (18.10. 15.90 and 22.00 ) were obtained from does mated $1^{\text {st }}$ day post-partum with 35 days weaning age, respectively.

On the basis of these results we can concluded that, does of the forth group (does mated $5^{\text {th }}$ day post-partum and their litters weaned at 35 days weaning agel had the highest body welghts, RGR\%, average DG, earcass traits and shared with it the sixth group (does mated $10^{\text {th }}$ day post-partum and their litters weaned at 35 days weaning age) In higher pereentage of carcass tralts. 
- Number of does gre mated and Utters reaned presented in Table (1).

\begin{tabular}{|l|c|c|c|c|c|c|}
\hline \multirow{2}{*}{ RI } & \multicolumn{2}{|c|}{ R1 } & \multicolumn{2}{c|}{ RS } & \multicolumn{2}{c|}{ R10 } \\
\cline { 2 - 6 } WA & Does & Litters & Does & Litters & Does & Litters \\
\hline W25 & 4 & 99 & 4 & 92 & 4 & 138 \\
\hline
\end{tabular}

Produetive trutis: 1. Pre wewaing growth: Weights were recarded difterent ages from birth biweekly, till weaning (25 or 35 days of age) It inciudes: a. Body weight bally foed consumption. Relative growth rare (RGR). It was caleulated according to Brody (1945). Relalive growth rale $=$ W2.WI $\times 100$

\section{$0.5(+2-1)$}

W: body wogh: al the begiuning of the period

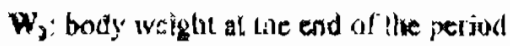

\section{Post weaning growth.}

\section{Mortality and vinbilty.}

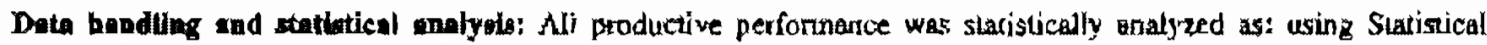
Analysis System Package (SAS, 2002)

The mathemutied model: To erralyze the effeel of ramating intervals and weang ages on the stodied traits in the present investigation, the following model was assumed.

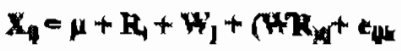

Symbols in the modal are defloed ax following:

$\mathbf{X}_{4} \quad$ is the observation on the rabbits.

H. $\quad$ is an effer common to all rabbils in the popputation.

R $\quad:$ is an eftect due to remacing ittervals; i = (i.e. 1 I I day posl partum, 5 - 5 th day pos partum, 10-100h day posi partum

W, $\quad$ is an elfeet die to weating ages; $j=$ (i, $e_{x} l=25$ days wesning age, $2=35$ days weaning age.

(RXW) is is effeci due to the interaction between remaling intervals and weaning ages.

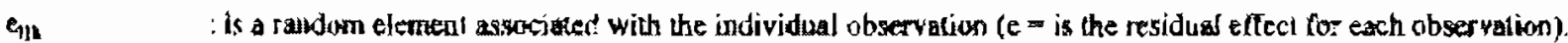


Tablo (1): The effect of Rcmating Interval, Weaning Age and their Interactions (LSM \pm SE) on Preweaning Relative Growth Rate at the first 25 and 35 days $\%$ of age.

\begin{tabular}{|c|c|c|c|c|c|c|c|c|}
\hline Trwits & \multicolumn{8}{|c|}{ Prewening Rolattve Growth Rete $X$} \\
\hline Age perind & \multicolumn{4}{|c|}{$\begin{array}{l}\text { Reletiva growith rate } \\
\text { (25 dafs) }\end{array}$} & \multicolumn{4}{|c|}{$\begin{array}{l}\text { Relotive prowth rate } \\
\text { (Is dayu) }\end{array}$} \\
\hline 1. Remutio interral. (RD) & $\mathbf{N}$ & Men & \pm & $\mathbf{S E}$ & $\mathbf{N}$ & Men & \pm & S. $\overline{\mathbf{E}}$ \\
\hline a $1^{\prime \prime}$ day after kindling. & 22 & $61.24^{\circ}$ & \pm & 3.25 & 11 & $70.00^{\circ}$ & \pm & 3.43 \\
\hline b. $5^{\text {th }}$ day alter landling. & 32 & $64.64 "$ & \pm & 2.75 & 16 & $72.83^{\circ}$ & $t$ & 3.39 \\
\hline 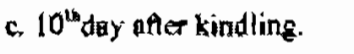 & 26 & $61.34^{\circ}$ & \pm & $\$, 18$ & 13 & $71, \$ 4^{\circ}$ & \pm & 336 \\
\hline 2. Wegning are (WA) & & & & & & & & \\
\hline 25 days & $\$ 0$ & $62.58^{\circ}$ & \pm & $2 \times 53$ & & & ـ & \\
\hline b. 35 days & 40 & $62.23^{\circ}$ & \pm & 2.49 & 40 & $72,7^{\prime \prime}$ & \pm & 3.82 \\
\hline 1. Remoting interral and & & & & & & & & \\
\hline 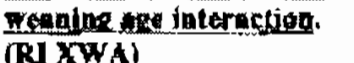 & & & & & & & & \\
\hline$I^{*}$ day (ll) 25 days (WN) & 11 & $60.86^{\circ}$ & $\star$ & 4.70 & & & ـ & \\
\hline 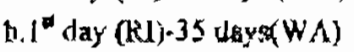 & 1: & $63.75^{\prime \prime}$ & \pm & 3.90 & 11 & & & \\
\hline c. $5^{\text {th }}$ day (RJ)-2S Uays WA) & 13 & $61.63^{\prime \prime}$ & * & 190 & & & - & \\
\hline d. $S^{\text {day }}(\mathrm{AJ})-35$ doys (W/ $)$ & $1 ?$ & $65.54^{\prime}$ & \pm & 4.50 & 16 & & & \\
\hline c.10 day(RI)-25 days(WA) & 13 & $61.36^{\circ}$ & \pm & 4.50 & & 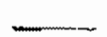 & - & {[} \\
\hline 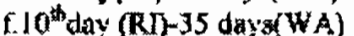 & 13 & $61.31^{\circ}$ & \pm & 4,30 & 13 & - & & _. \\
\hline
\end{tabular}

Table (2): The effecl of Remating interval, Weaning Age and their Intersctions (LSM \pm SE) on Postweaning Hetairyc Growh Pate $Y$ at $6-8$ and $8-10$ weks of age.

\begin{tabular}{|c|c|c|c|c|c|c|c|c|}
\hline Tralts & & & $P$ & atog $n$ & gro & $\tan \alpha$ & & \\
\hline Age period & & & ats: & & & $8-10$ & & \\
\hline 1. Reppting interval (RT) & $\bar{N}$ & Mean & \pm & S. E. & $\mathrm{N}$ & Mean & \pm & S. \\
\hline a. $1^{2}$ day after kindling & 22 & $42.77^{\circ}$ & \pm & 1.10 & 21 & $32.89^{64}$ & \pm & 0.83 \\
\hline b. $5^{\text {th }}$ day after kindling. & 31 & $44.28^{\prime \prime}$ & \pm & 0.96 & 31 & $3.86^{\circ}$ & \pm & 0,99 \\
\hline 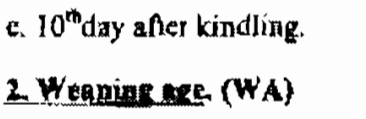 & 25 & $33.82^{b}$ & $\mathbf{t}$ & 1.13 & 23 & $30.82^{b}$ & $\star$ & 0.94 \\
\hline R. 23 days & 39 & $3823^{h}$ & \pm & 0.85 & 36 & $31.79^{b}$ & \pm & 0.76 \\
\hline 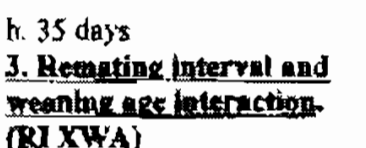 & 39 & $42.36^{\circ}$ & \pm & 0.89 & 39 & $33.26^{\prime \prime}$ & * & 0.70 \\
\hline a day (RI)-25 days (WA) & lI & $44.5 I^{*}$ & * & 1.42 & 10 & $32.36^{\circ}$ & $\star$ & 1.22 \\
\hline b.1" day (RI)-35 daja (W'A) & 11 & $44.06^{\mathrm{b}}$ & \pm & 1.31 & 11 & $33.23^{x}$ & \pm & 1.13 \\
\hline$c 5^{\text {th }}$ day $(\mathrm{R})-25$ dwys( $\left.\mathrm{HiA}\right)$ & 15 & $36.60^{\star}$ & \pm & 1.48 & 15 & $31.61^{\circ}$ & 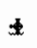 & 1.28 \\
\hline d. $5^{\text {th }}$ day (RI) 35 days (WA) & 16 & $48.94^{*}$ & * & 1.62 & 16 & $35,61^{*}$ & \pm & 1.36 \\
\hline c. $10^{\text {th day }}(\mathrm{RI})-25$ deyo(WA) & 12 & $33.58^{t}$ & \pm & 1.35 & 11 & $30.02^{4}$ & \pm & 1.40 \\
\hline$\left[.10^{\circ}\right.$ day $(\mathrm{R})-15$ davs $(\mathrm{V} / \mathrm{A})$ & 13 & $34.07^{6}$ & \pm & 165 & 12 & $32.11^{\circ}$ & \pm & 1.43 \\
\hline
\end{tabular}


Table (3): Tbe effect of Remaling Intervat. Weaning A and their lnteractions (LSM $\pm 5 E$ ) on Postweaning Relative Growth Rate $\%$ at 10-1 $2,12-14$ weeks of age and $14-18$ weeks of age.

\begin{tabular}{|c|c|c|c|c|}
\hline Tralks & \multicolumn{4}{|c|}{ Poshreaning retattre growth rate (7) } \\
\hline Age period & \multicolumn{2}{|c|}{$10-12$ wats } & \multirow{2}{*}{$\begin{array}{c}\text { 12-14 wealcos } \\
\text { Mean } \pm \text { S. } \mathrm{E} .\end{array}$} & \multirow{2}{*}{$\begin{array}{l}1416 \text { wadks } \\
\text { Mean } \pm \text { S. E. }\end{array}$} \\
\hline 1. Bemation interval $(\mathbf{R})$ & $\mathbf{N}$ & Mean \pm S. E. & & \\
\hline a. $1^{\sigma}$ day after kindling & 19 & $21.73^{*} \neq 1.08$ & $17.85 \div 0.49$ & $14.94 "=0.37$ \\
\hline b. $5^{\text {thay }}$ dter kindling. & 24 & $24.62^{\circ}+1.25$ & $18.98 * 0.42$ & $16.00^{\circ} \pm 0.33$ \\
\hline c. $10^{\text {th }}$ day after kindling. & 22 & $22.61^{\prime} \pm 1.20$ & $17.78^{4} \pm 0.51$ & $15.21 " \pm 0.40$ \\
\hline \multicolumn{5}{|l|}{ 2. Waraiog ote, (WA) } \\
\hline a. 25 days & 33 & $19.44^{b} \pm 0.98$ & $17.04^{\vee} \neq 0.41$ & $14.69^{6} \pm 0.32$ \\
\hline $\begin{array}{l}\text { b. } 35 \text { days } \\
\text { 3. Rempting intervel and wesping }\end{array}$ & 32 & $2.6 .53^{*} \pm 0.94$ & $19.36^{*} \pm 0.37$ & $1613 \times 0.28$ \\
\hline gpe laterextion. & & & & \\
\hline $\begin{array}{l}\text { (RU XWA) } \\
\text { a day (RI)-25 days (WA) }\end{array}$ & 9 & $24.04 \times 1.58$ & $17.82^{2} \pm 0.76$ & $15.11=0.59$ \\
\hline b. $1^{\text {day }}(\mathrm{Rl})-35$ days WAI & 10 & $19.42^{x} \pm 1.47$ & $17.45^{2} \pm 0.59$ & $14.684+0.44$ \\
\hline $6.5^{\text {th }}$ day (RI)-25 Jays (WA) & 12 & $26.13^{5} \pm 1.61$ & $17.88^{*} \pm 0.63$ & $14,77^{x} \pm 0,45$ \\
\hline d. $5^{L}$ day (RI-35 days(WA) & 12 & $29.38^{2} \pm 1.72$ & $20.50^{\circ} \pm 0.60$ & $17.494+00.49$ \\
\hline e. $10^{\ln J u y(R D)}-25$ daysi $\left.W A\right)$ & 11 & $19.04^{\circ} \pm 1.7 ?$ & $15.89^{*} \pm 0.73$ & $16.14:=0.51$ \\
\hline f. $10^{\text {th }}$ day $(\mathrm{Rl})-35$ days $(W / A)$ & $\$ 1$ & $19.86^{\prime} \pm 1.82$ & $19.70^{\circ} \pm 0.69$ & $14.29 "=0.62$ \\
\hline
\end{tabular}

Twbe (4): The effex of Remating Tnervai, Weaning Age and their Interactions (LSM \pm SE) on Preweaniog Average Daify Gain (g) at the first 25 and 35 days of age.

\begin{tabular}{|c|c|c|c|c|c|c|c|c|}
\hline Tralta & \multicolumn{8}{|c|}{ Prewexnlog arerege dally gets (g) } \\
\hline Age period & \multicolumn{4}{|c|}{ 24 day? } & \multicolumn{4}{|c|}{35 day } \\
\hline 1. Romating interval (RI) & $\mathbf{H}$ & Mean & $\star$ & S. E. & $\mathbf{Y}$ & Mena & \pm & S. B. \\
\hline a. I" day afted kindinng. & 22 & $37.05^{*}$ & \pm & 3.07 & 11 & $47.56^{2}$ & \pm & 2.87 \\
\hline b. $5^{\text {th }}$ dey after kindiing. & 32 & $47.34^{*}$ & \pm & 2.66 & 16 & $55.55^{*}$ & \pm & 2.87 \\
\hline c. $10^{\text {th }}$ day after kindling & 26 & $42,18^{\mathrm{D}}$ & \pm & 3.07 & 13 & $54,33^{\prime \prime}$ & $士$ & 2.48 \\
\hline \multicolumn{9}{|l|}{ 2. Weapiag age. (WA) } \\
\hline a. 25 days & 40 & $43.34^{*}$ & \pm & 2.40 & & 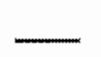 & & - \\
\hline h, 35 days & 40 & 41.07 & \pm & 2.40 & 40 & $53.50^{\prime \prime}$ & \pm & 2.24 \\
\hline 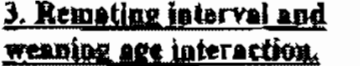 & & & & & & & & \\
\hline (RIXWA) & & & & & & & & - \\
\hline a. 1 dsy $(R]$ ) 25 days (WA) & 11 & $36.94^{2}$ & \pm & 4.34 & & & & \\
\hline b. $1^{*}$ day (KD-35 dajs(WA) & 11 & $46.28^{\star}$ & 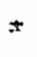 & 3.76 & II & & & \\
\hline$c, 5^{\text {th }}$ day (RI)-25 duys(WA) & $1 \$$ & $48.41^{\circ}$ & \pm & 3.76 & & - & & $\longrightarrow$ \\
\hline d. $5^{\text {th }}$ day (RI)-35 dajs (WA) & 17 & $37,16^{4}$ & \pm & 4,34 & 16 & - & & - \\
\hline 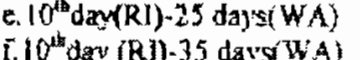 & 13 & $44.44^{4}$ & \pm & 4,34 & & $\sqrt{2}$ & & {[} \\
\hline [. $10^{80} \mathrm{dav}(\mathrm{R})-35$ days WA & 13 & $39.91^{\circ}$ & \pm & 4,34 & 13 & & & 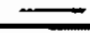 \\
\hline
\end{tabular}


Tabte (5) The effect of Rematiag Interval. Weaning Age and their Interactions (LSM \pm SE) on Postweanimg Averace Drily Gain $(\mathrm{g})$ at $6-8$ and $B-10$ weets of qge.

\begin{tabular}{|c|c|c|c|c|c|c|c|c|}
\hline Tratts & \multicolumn{8}{|c|}{ 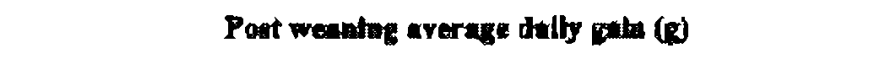 } \\
\hline Ater period & \multirow{2}{*}{$\mathbf{N}$} & \multicolumn{3}{|c|}{$6-8$ weth } & \multicolumn{4}{|c|}{ 8-10 } \\
\hline 1. Rementine htronel (R) & & Menn & \pm & S. $\mathbf{E}$ & $\mathbf{N}$ & Mena $\neq$ & 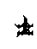 & $\mathbf{S} \mathbf{R}$ \\
\hline 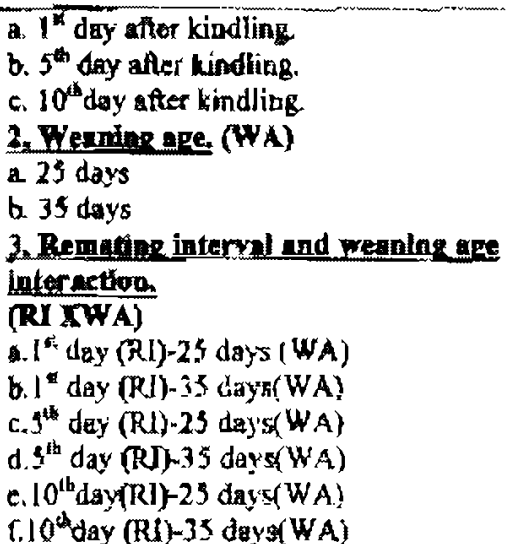 & $\begin{array}{l}22 \\
31 \\
25 \\
34 \\
39\end{array}$ & $\begin{array}{l}23.15^{\mathrm{x}} \\
24.05^{\circ} \\
18.38^{\circ} \\
18.41^{\circ} \\
25.31^{\circ}\end{array}$ & $\begin{array}{l} \pm \\
\pm \\
= \\
\pm \\
\pm \\
\pm\end{array}$ & $\begin{array}{l}0.81 \\
0.74 \\
0.84 \\
0.92 \\
0.88 \\
0.94\end{array}$ & $\begin{array}{l}10 \\
11 \\
15 \\
16 \\
11 \\
12\end{array}$ & $\begin{array}{l}22.16^{\star} \\
25.94^{\mathrm{bb}} \\
22.92^{\mathrm{b}} \\
28.61^{\mathrm{b}} \\
21.36^{\mathrm{b}} \\
27.22^{\mathrm{\omega}}\end{array}$ & $\begin{array}{l} \pm \\
\pm \\
\pm \\
\pm \\
\pm \\
\pm\end{array}$ & $\begin{array}{l}0.87 \\
0.99 \\
0.97 \\
1.02 \\
0.91 \\
0.80\end{array}$ \\
\hline
\end{tabular}

Tahle (6); The effect of Remaring interval, Weaning Age and their Inlesacliong (LSM \pm SE) on Postweaning Average Daily Gain (g) a $10-12,12-14$ weels of age and 14-16 weths of age.

\begin{tabular}{|c|c|c|c|c|}
\hline Pralts & \multirow{3}{*}{$\mathbf{N}$} & \multicolumn{3}{|c|}{ Peat weaning a rerage dulty gatu (v) } \\
\hline Ago perlod & & 10.12 werlex & 12-14 Weals & 14-16 Weales \\
\hline 1. Remuting laterol. (RN) & & Mean $\pm 5 . \mathbf{L}$ & Meas $\pm 5 . L$ & Mean $\neq S$ \\
\hline 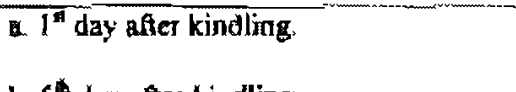 & 19 & $20.84^{k} \pm 0.95$ & $22.11^{*}+6.76$ & $\begin{array}{c}22.10^{\circ} \pm \\
0.61\end{array}$ \\
\hline b. $5^{\text {th }}$ day atter kindling. & 24 & $24.58 \times 1.10$ & $22.25 \pm 0.73$ & $22.555^{a} \pm 0.68$ \\
\hline 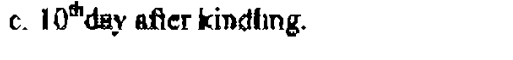 & 22 & $23.75: \pm 1.05$ & $22.14=0.63$ & $22.63 \pm 0.74$ \\
\hline 1. Wening mes (WA) & & & & \\
\hline a. 25 days & 33 & $22.07 * 0.86$ & $21.66^{*} \pm 0.53$ & $21.31^{k} \pm 0.52$ \\
\hline 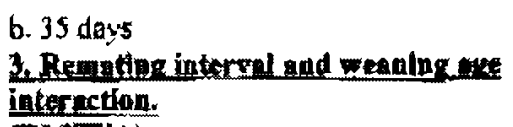 & 32 & $24.05 \times 0.83$ & $22.68 * 10.60$ & $23.59 \times 0.59$ \\
\hline $\begin{array}{l}\text { (RIXWA) } \\
\text { al" day (RI)-25 days (WA) }\end{array}$ & 9 & $21.18^{*} \pm 1.39$ & $22.48^{\wedge} \pm 0.89$ & $22.57^{\prime} \pm 0.50$ \\
\hline b. $1^{\alpha}$ day (RI)-35 daysa(WA) & 10 & $20.50^{\circ} \pm 1.29$ & $20.22^{*} \neq 0.94$ & $20.01+0.83$ \\
\hline$c 5^{\text {th }}$ day (RT)-25 days(WA) & 12 & $24.64 * 1.42$ & $21.79^{\circ} \pm 0.88$ & $21.63 \pm 0.82$ \\
\hline 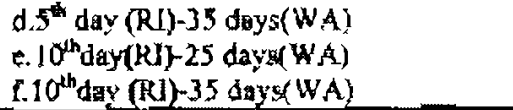 & $\begin{array}{l}12 \\
11 \\
11\end{array}$ & $\begin{array}{l}26.32^{4} \pm 1.51 \\
22.87^{*} \pm 1.56 \\
22.84^{4} \pm 1.60\end{array}$ & $\begin{array}{l}24.27^{*} \pm 1.13 \\
22.27 * 1.03 \\
21.96^{\circ} \pm 1.12\end{array}$ & $\begin{array}{l}25.10^{2} \pm 1.09 \\
21.35 \pm 0.95 \\
23.91 \pm 1.15\end{array}$ \\
\hline
\end{tabular}


Table (7): The effect of Remating Interval, Weaning Age aud their lnteraction (LSM \pm SE) on Fore part Inlermedinta par $\%$ and Ilind pan $\%$.

\begin{tabular}{|c|c|c|c|c|}
\hline \multirow{2}{*}{ Classifreatiens } & \multicolumn{4}{|c|}{ Carcan cub } \\
\hline & \multicolumn{2}{|c|}{ Fore pant $x$} & \multirow{2}{*}{$\frac{\text { Iatermedlate part of }}{\text { Mean } * \text { S. C. }}$} & \multirow{2}{*}{$\frac{\text { Fimd part } \%}{\text { Mean } \pm \text { S. } \mathbf{L}}$} \\
\hline 1. Remating baternel (R) & $\mathbf{N}$ & Mean \pm S. E & & \\
\hline a. Ist day afier kindling. & 10 & $19.10^{4 t}+0.80$ & $18.70^{\mathrm{at}}=0.70$ & $23.70 * 0.11$ \\
\hline b. 5th day after kindling & 10 & $22.30^{*} \pm 0.80$ & $20.20 \times 0.70$ & $25.10^{\prime} \pm 0.11$ \\
\hline c. IOWhday after kindling. & 10 & $22.30^{\star x}=0.90$ & $20.19^{2}+0.80$ & $25.10^{4} \pm 0.11$ \\
\hline \multicolumn{5}{|l|}{ 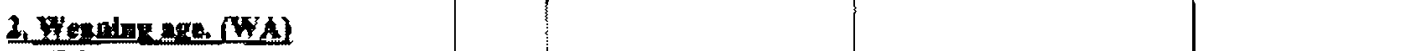 } \\
\hline a. 25 days & 15 & $19.9^{\circ} \pm 0.70$ & $17.411^{6}=0.60$ & $23.50^{4} \pm 0.90$ \\
\hline b. 35 days & 15 & $22.6^{\circ} \pm 0.70$ & $20.40^{1} \pm 0.60$ & $24.40^{n}=0.90$ \\
\hline \multicolumn{5}{|l|}{ 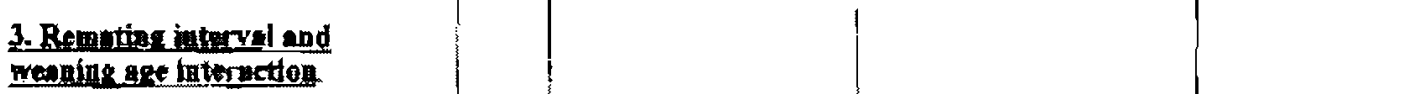 } \\
\hline $\begin{array}{l}\text { (RIXWA) } \\
\text { a I sl day (RI-1S days (WAj) }\end{array}$ & 3 & $21 \times 60^{n+1} \pm 0,11$ & $19.0 x^{4} \pm 0.10$ & $24.60^{\circ} \pm 0.14$ \\
\hline Q.19t day (RI)-35 day (WA) & 3 & $18.10^{\mathrm{k}} \pm 0.11$ & $15.900^{6} \pm 0.10$ & $22.00 \div 0.14$ \\
\hline c.5th day (RI)-2s days (WA) & 5 & $21,0,00^{\mathrm{tb}} \pm 0,13$ & $18.40^{16} \pm 0.11$ & $22.80^{\prime} \times 0.16$ \\
\hline d. 5 th day (RI)-35 days (WA) & 5 & $26.19 \pm 0.13$ & $2260^{2} \pm 0.11$ & $26.39^{\circ}=0.16$ \\
\hline E.10didny(RI) 25 days (WA) & 5 & $19.90^{t+} \pm 0.13$ & $\left\lfloor\overline{3} .40^{a b} \cdot 0.11\right.$ & $23.80^{\circ} \pm 016$ \\
\hline [10hdey (RI) 35 dars (WA) & 5 & $26.20^{4} \pm 0.13$ & $22.61^{2} \neq 0.13$ & $28.40^{\circ}=0.15$ \\
\hline
\end{tabular}

Means within the sanc category having different superscripts are significant!y difrerent al level $(\beta \leq 0,03)$. 


\section{REFERENCES}

Azoz, A. A. (1996) : Effect of different matIng system on rcproductuve and productive $\mathrm{e}^{\mathrm{r}}$. ficlency of rabbits. M.Sr. thests. Faculty of Agric., Calro Unlv. Egypt.

Azom, A A (2001) : Effect of rematung interval on reproductive and productuve performance of rabbits. Ph. D., thests. Faculty of Agric., Calso Untw., Egypt.

Brody, 8. (1945) : Bioenergetlo and growth. Reinhold Pub Crop N. Y., U.S.A

Deneraz, G.; Macart, M.; Machado, C. R.; Chol, J. 8. and Friend, M. B. (1981) : Annual report of studies in animal nutrition and al. lled sclences. Volume 38, 1981. Annual report of studtes in animal nutrtion and allicd sct ences. Volume 38. $1981 ; 138 \mathrm{pp}$.

Chen, C. P.: D. R., Rao; G, R., Sunkl and W. M., Johnuon (1978) : Effect of weanung and slaughter ages upon rabblt meat producUon 1. Body Welght Feed Efficlency and Mortality. J. Antm Sc1 . 46:573 - 577.

Das, S. K. and Bujarbarua, K. M. (2007) : Effect of weaning age on the performances of rabblt in the sub temperate Eastern Hirnalayon region of India. Indian Journal of Anumal Regearch. Volume: 41. Issue: 4 , print ISSN: 0367-6722.

De- Daa, J. C.; Perex, E.; Praga, M. J.; Rodriguex, J. M. and Galvaez, J. F. (1081): Effect of diet on feed intake and growth of rabblts from weanlng to slaughter at different ages and welghts. J. Antm. Scl., 52, 12251232

Dlwyato, M.; Gambacorta, M. and grtvantava (1985) : Eflect of remating interval and reeding on milk production in New Zealand doe rabbits Investugatulon Agrana, produccton- $Y$ = Sandidad. AnImalcs. 1985; 1 (1.2) :55-64.
Fokote, B.; Gippert. T.: Prenzcl, J. and Sirko, E. (1084) : Fyber, proteln interaction In nutrition of rabbits. Allattenyeer Takar Manyozas $33(2) 163-171$,

Gallots, M.; Gldenne, T. and Fortune-

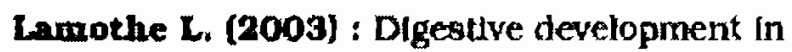
the young rabbit: impact of a weaning at 21 d. In: Proc. 3rd Meetings of Work group 3rd and 4th Cost Action 848. Prague, Czech Repubhle, 15 PP.

Ruo, D. R,; Chen, C. P.; G. R., Suntd and W. M., Johnaton (1978) : Effect of wcaning and slaughter ages upon rabblt meat production. 1. Body Welght. Feed Emclency and Mortallty. J. Anum Scl : $46: 573-$ 577.

Romney, C. P. and N. P., Johnoton. (1978) : Dietary protein levels and early weaning on rabblt performance.Proc. West Secl. Anter. Soc. Antm. Sc1. 29: 201.

Toeon, M. A, A A, Abdel-Hakim and $Z$. B. H., Ruble (1996) : Effect of remating interval and type of mating on some productive and reproductuve performance tralts of rab. bits, Egyptian d. of Rabbits Sclence, 5 (1), 3342.

Mendex, J.; J. C., De Blas and M. J., Frage (1980) : The effects of diet and remating Interval after parturition on the reproductive performance of the commerclal doe rabblts. J. Anlm. Scl., 26, 6: 1624.

Partridge, G. G.; G. J., Allan; M., Findlay and $W_{.,}$Corrigall (1084) : The effects of reducing the remating Interval after parturtion on the reproductive performanee of the Commerctal doe rabbt. J.Antm prod., 39 : 465.

(EAS) (2002) : Staustical Analysts System, SAS/ STAT user's Gutde, SAS Institute, Inc.. Cary NC 27513, US. 
Trom

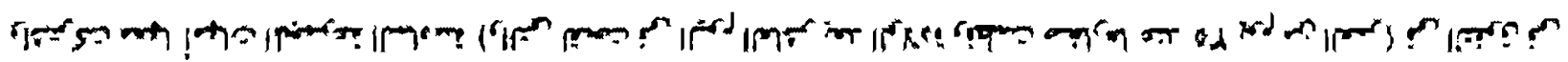

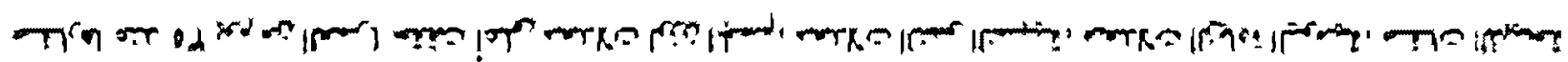

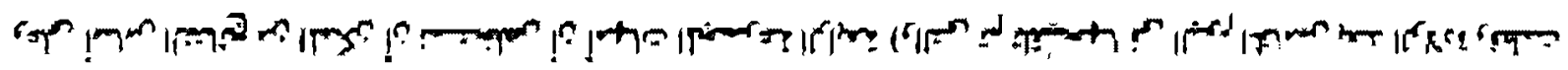

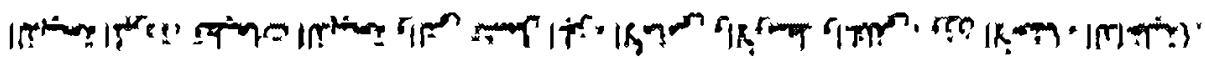

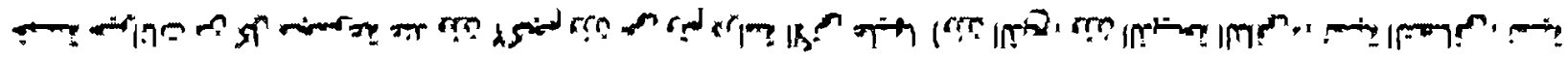

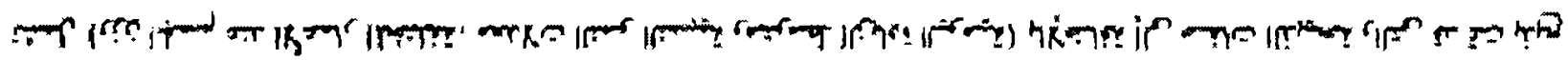
ח

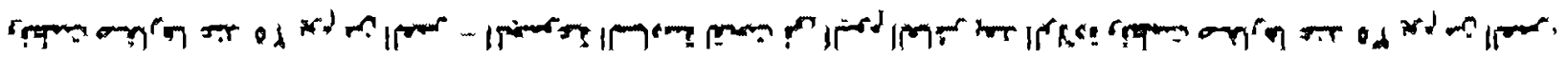

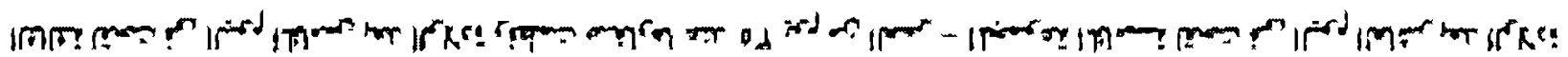

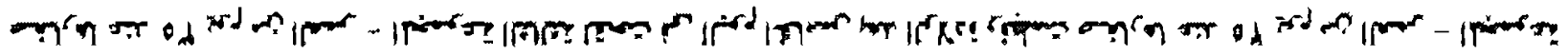

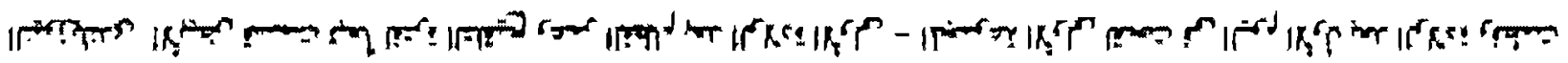

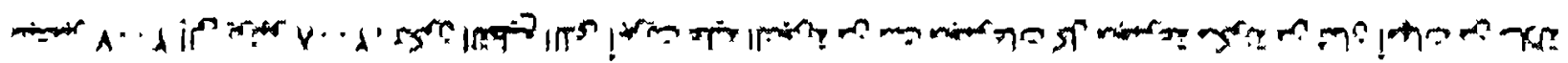
1

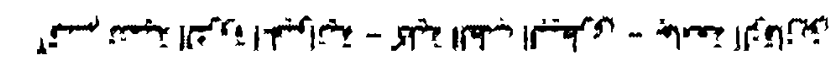

IF

oner nar gres

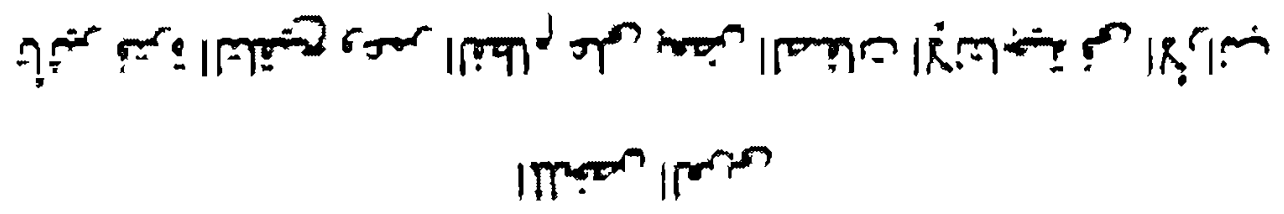

